\title{
Implications of water hardness in ecotoxicological assessments for water quality regulatory purposes: a case study with the aquatic snail Biomphalaria glabrata (Say, 1818)
}

\author{
Oliveira-Filho, EC. ${ }^{a, b *}$, Caixeta, NR. ${ }^{a, b}$, Simplicio, NCS. ${ }^{a, b}$, \\ Sousa, SR. ${ }^{a}$, Aragão, TP. ${ }^{a, b}$ and Muniz, DHF ${ }^{a}$ \\ ${ }^{a}$ Embrapa Cerrados, Rodovia BR 020, Km 18, CEP 73310-970, Planaltina, DF, Brazil \\ bCentro Universitário de Brasília - UniCEUB, SEPN 707/907, Asa Norte, CEP 70790-075, Brasília, DF, Brazil \\ *e-mail: eduardo.cyrino@embrapa.br
}

Received: November 6, 2012 - Accepted: January 22, 2013 - Distributed: February 28, 2014

(With 1 figure)

\begin{abstract}
Water hardness is a property depending on the presence of alkaline earth metals, mainly calcium and magnesium. Among the strategies for water quality monitoring, ecotoxicological assays are performed to minimize impacts and classify water bodies. For these laboratory evaluations parameters are previously defined in the guidelines, including water hardness for both cultivation and testing medium. The present work was performed to evaluate the effects of different levels of water hardness on the survival and reproduction of the freshwater snail Biomphalaria glabrata and discuss the influence of natural water hardness on the results of ecotoxicological tests with these environmental samples. Comparing the groups it was possible to observe that those maintained in waters with least hardness had lower reproductive success, while the groups maintained in highest hardness showed better reproduction. These data show that waters with low hardness make the reproduction of the snail B. glabrata unfeasible, and this reveal a problem for ecotoxicity assays using natural water samples.
\end{abstract}

Keywords: ecotoxicology, biological assays, standard methods, guidelines, environmental factors.

\section{Implicações da dureza da água nas avaliações ecotoxicológicas com propósitos reguladores de qualidade da água: um estudo de caso com o caramujo aquático Biomphalaria glabrata}

\begin{abstract}
Resumo
A dureza da água é uma propriedade dependente da presença de metais alcalino terrosos, principalmente cálcio e magnésio. Entre as estratégias para monitorar a qualidade da água ensaios ecotoxicológicos são realizados para minimizar impactos e classificar os corpos hídricos. Para essas avaliações em laboratório, parâmetros são previamente definidos nos protocolos, incluindo a dureza da água para cultivo e para a água de diluição. O presente trabalho foi realizado para avaliar os efeitos de diferentes níveis de dureza da água sobre a sobrevivência e a reprodução do caramujo de água doce Biomphalaria glabrata e discutir a influência da dureza de águas naturais nos resultados dos testes ecotoxicológicos com estas amostras ambientais. Comparando os grupos foi possível observar que aqueles mantidos em águas com menor dureza tiveram pior sucesso reprodutivo, enquanto os mantidos nas águas com maiores durezas tiveram melhor reprodução. Esses dados mostram que águas com baixas durezas tornam a reprodução do caramujo B. glabrata inviável, e esse fato revela-se como um problema para os ensaios ecotoxicológicos utilizando amostras de água naturais.
\end{abstract}

Palavras-chave: ecotoxicologia, ensaios biológicos, métodos padrão, protocolos, fatores ambientais.

\section{Introduction}

Water is one of the natural resources essential to sustaining life. However, nowadays aquatic ecosystems have undergone profound changes, mostly arising from human activities. To diagnose problems related to pollution of aquatic environments, it has become necessary to adopt control methods and strategies for monitoring their quality.

For this aspect, in Brazil, CONAMA Resolution No357/05, published on March 17, 2005 (Brasil, 2005), establishes maximum allowable values for various physical, chemical and biological parameters as limiting for water quality, and its innovation lies in the determination of acute and chronic ecotoxicological effects as a quality criterion related to the maintenance of aquatic life.

Regarding laboratory observation of chronic effects on aquatic species, although the seven-day Ceriodaphnia dubia survival and reproduction test is one of the most adopted 
(Oliveira-Filho et al., 2008), alternative and often more sensitive tests have been evaluated (Oliveira-Filho et al., 2009a, b, 2010), with wide application potential, including tests with environmental samples.

In any case, ecotoxicological testing is not simple, and in this context, seeking standardization of the methods used, governmental agencies such as the Brazilian Association of Technical Standards (ABNT) and the United States Environmental Protection Agency (USEPA) have defined strategies and protocols for tests with aquatic organisms. Among the various standards set, there is the establishment of different hardness ranges of cultivation water of test species, but the hardness to be used in the test dilution water is normally fixed in the range between 40 and $48 \mathrm{mg} / \mathrm{L} \mathrm{CaCO}_{3}$, in Brazil (ABNT, 2004, 2005) or between 100 and $180 \mathrm{mg} / \mathrm{L} \mathrm{CaCO}_{3}$, in the United States (USEPA, 2002).

Water hardness is a property arising from the presence of alkaline earth metals, especially calcium and magnesium, which are found in natural waters. This property mainly results from the dissolution of soil minerals and rocks, and can also be caused by direct contamination by waste from a number of anthropogenic sources (Wurts, 1993). The different levels of water hardness can be classified as follows (as $\mathrm{mg} / \mathrm{L} \mathrm{CaCO}_{3}$ ): soft water, $0-75$, moderately hard water, 75-150; hard water, 150-300, and very hard water, > 300 (USEPA, 1976).

While national standards are set, in Brazil there are several studies on the characterization of surface waters, and the results show wide variation in the water hardness around the country. With values in $\mathrm{mg} / \mathrm{L} \mathrm{CaCO}$, variation was observed in the Southeast from $<1$ to 178 (Aragão et al., 2003; Savoy et al., 2004), in the North $<1$ (Horbe et al., 2005), in the Central region from 0 to 63.8 (Muniz et al., 2011) and in the Northeast from 1.3 to 2999.6 (Brito et al., 2005).

Thus, as CONAMA Resolution Nº357/05 (Brasil, 2005) recommends ecotoxicological testing as an additional parameter for assessing water quality, and as there is sometimes a gap between the water hardness standards for laboratorial cultivation of species and those found in field samples, the objective of this study was to evaluate the effects of changing conditions of water hardness on survival and reproduction of Biomphalaria glabrata snails, in order to emphasize the degree of accuracy that this parameter can generate in the results of ecotoxicological assays with environmental samples and consequently in water quality standards.

\section{Material and Methods}

\subsection{Tested waters}

To assess the biological effect of water hardness, four waters with different hardness levels were defined for testing. The first was a natural water (NW) obtained from a spring in the area of Embrapa Cerrados, in Planaltina, Federal District, Brazil (15 $35^{\prime} 41.5^{\prime \prime} \mathrm{S}$ and $\left.47^{\circ} 44^{\prime} 45.3^{\prime \prime} \mathrm{W}\right)$, with hardness about $2 \pm 1 \mathrm{mg} / \mathrm{L} \mathrm{CaCO}_{3}$, and the other three were reconstituted waters prepared according to the guidelines described by ABNT (2004) and with the following standards of hardness in $\mathrm{CaCO}_{3}: 10 \pm 2 \mathrm{mg} / \mathrm{L}$, soft water (SW1); $40 \pm 5 \mathrm{mg} / \mathrm{L}$, soft water (SW2) and $120 \pm 2 \mathrm{mg} / \mathrm{L}$, moderately hard (MH1) all using distilled water with added salts according to this standard protocol. Reconstituted waters were prepared to be used with dilutions in distilled water of a stock solution with $\mathrm{NaHCO}_{3}(48 \mathrm{mg}), \mathrm{CaSO}_{4} \cdot 2 \mathrm{H}_{2} \mathrm{O}$ (30 mg), $\mathrm{MgSO}_{4} \cdot 7 \mathrm{H}_{2} \mathrm{O}(614 \mathrm{mg})$, and $\mathrm{KCl}(2 \mathrm{mg})$, in agreement with ABNT (2004). All waters had pH defined at $7.2 \pm 0.1$ and the natural water was filtered through $28 \mathrm{~mm}$ to remove potential nutrients and suspended materials. This natural water has been periodically evaluated to determine the presence of metal contaminants, anionic and cationic nutrients and fecal coliforms, and is considered of excellent quality and classified as Class 1 by CONAMA Resolution 357 (Brasil, 2005). This water has been used for more than five years to the cultivation of Ceriodaphnia dubia in laboratory, after reconstitution and obtaining hardness patterns in the range between 40 and $48 \mathrm{mg} / \mathrm{L}$ as $\mathrm{CaCO}_{3}$, and $\mathrm{pH}$ adjustment to the range of $7.0 \pm 0.2$. The $\mathrm{pH}$ of the water in natural conditions is always around $6.5 \pm 0.2$ and it was maintained for the present study design.

\subsection{Analysis of total hardness}

For each sample of natural water collected and each preparation of synthetic water, analyses of total hardness were performed to check and evaluate maximum and minimum variations. This procedure was performed at the Laboratory of Water Chemistry at Embrapa Cerrados by EDTA-Na titration method (ABNT, 1992).

\subsection{Survival and reproduction of Biomphalaria glabrata snails}

The snails of the Biomphalaria genus are aquatic pulmonates; they are widely distributed throughout Brazilian territory and are organisms whose biology and ecology have been well studied, especially because they are intermediate hosts of Schistosoma mansoni. Also, they are native to freshwater ecosystems, which is why many authors propose their use as test organisms in ecotoxicological assays (Ravera, 1977; Bellavere and Gorbi, 1981; Münzinger, 1987; Oliveira-Filho et al., 2004, 2005). This species has been cultivated in the laboratory of ecotoxicology at Embrapa Cerrados, specifically for use in bioassays. The colony is maintained in synthetic soft water with $\mathrm{pH} 7.4 \pm 0.1$, hardness $40-48 \mathrm{mg} / \mathrm{L}$ as $\mathrm{CaCO}_{3}$, temperature $25 \pm 2{ }^{\circ} \mathrm{C}$ and photoperiod of 8 hours light and 16 hours dark. In this context, studies related to acute and chronic effects have been conducted, and one way to determine reproductive damage is through the quantitative assessment of the egg-laying of individuals, by counting the number of eggs and egg masses.

\subsection{Quantification of eggs and egg-masses}

In each tested type of water 20 adult snails (shell diameter 6-8 $\mathrm{mm}$ ) were exposed individually in beakers of $300 \mathrm{~mL}$. These organisms were maintained for 5 weeks in waters with different hardness and because they are 
hermaphrodites the evaluation of reproduction at the individual level was chosen as endpoint. To recover egg masses laid by snails, beakers were internally covered with cellophane sheets as suggested by Olivier and Haskins (1960) and adapted by Oliveira-Filho et al. (2009a, b, 2010). To determine the number of eggs and egg-masses counts were performed twice a week. On this occasion the water solution and the food were renewed, composed of a piece of fresh lettuce leaf (a piece of approximately $1 \mathrm{~cm}^{2}$ ) and a small flake of fish chow, and the respective water sample with its hardness evaluated. Counting the number of eggs was performed using a stereomicroscope. The reproductive performance was evaluated only after 5 weeks as the endpoint of the test performed.

After the collection of eggs and egg-masses, this material was kept in the original water of the parental generation (F0), to observe the development of newly hatched individuals from the F1 generation.

\subsection{Sensitivity of B. glabrata snails}

The sensitivity of the $B$. glabrata adult snails was tested with anhydrous copper sulfate $\left(\mathrm{CuSO}_{4}\right.$, Merck, 99\% purity) due to its known moluscicidal activity (OliveiraFilho et al., 2004). One acute 24 hours test for week was performed during the five weeks of reproductive evaluation using the water with reference hardness pattern of 40-48 $\mathrm{mg} / \mathrm{L}$ as $\mathrm{CaCO}_{3}$ (ABNT, 2004).

\subsection{Statistical analysis}

Differences in the number of eggs and egg-masses produced were evaluated by one-way ANOVA followed by Dunnett's multiple comparison test (Dunnett, 1955). Dunnett procedure software (Version 1.5) is available from the United States Environmental Protection Agency. Calculations were performed using the SW2 (40 mg/L) group as control, and assessing what means would be considered as significantly lower or higher than control with $\mathrm{p}<0.05$.

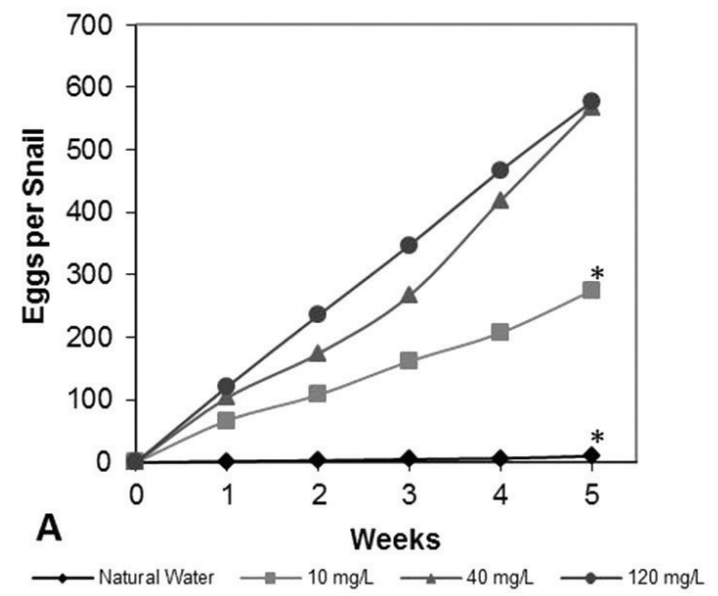

To evaluate the sensitivity of B. glabrata snails, 24 hours $\mathrm{LC}_{50}$ s were calculated by the Trimmed Spearman Karber Method (Hamilton et al., 1977).

\section{Results}

During the experimental period no mortality of the snails was observed in the different groups. The effects of different water hardness on the fecundity of B. glabrata adult snails, after five weeks, are shown in Figures 1A and 1B. The snails maintained at the two lowest hardnesses (NW and SW1) had a marked reduction in the number of eggs produced (Mean $\pm \mathrm{SE} ; \mathrm{NW}=10.1 \pm 9.7$; $\mathrm{SW} 1=256.2 \pm$ 47.4 eggs/snail) as compared to the number of eggs laid by SW2 snails ( $566.5 \pm 90.8$ eggs/snail). The observation was similar in relation to egg masses produced (Mean $\pm \mathrm{SE}$; $\mathrm{NW}=1.9 \pm 1.7 ; \mathrm{SW} 1=25.9 \pm 3.4 \mathrm{egg}$ masses/snail $)$ and SW2 (41.7 \pm 3.4 egg masses/snail).

No differences in egg production and egg-masses production were noted between the groups maintained at the two highest hardnesses, SW2 (Mean \pm SE; $566.5 \pm 90.8$ eggs/snail; $41.7 \pm 3.4$ egg masses/snail) and MH1 (Mean \pm SE; $576.9 \pm 141.6$ eggs/snail; $46.9 \pm 5.9$ egg masses/snail).

Among the egg-masses generated by the NW group, in general, one to two eggs appeared unfertilized. These eggs were not counted in the average obtained by the reproduction of the NW group. The hatching of the eggs remaining in this group was below $10 \%$ without survival later. The newly hatched individuals generated by the SW group were visually observed and had a light colored shell and were very small in size when compared to newly hatched individuals of the groups SW2 and MH1, which presented a greater number of individuals, with a dark brown-colored shell and the expected size for the development stage.

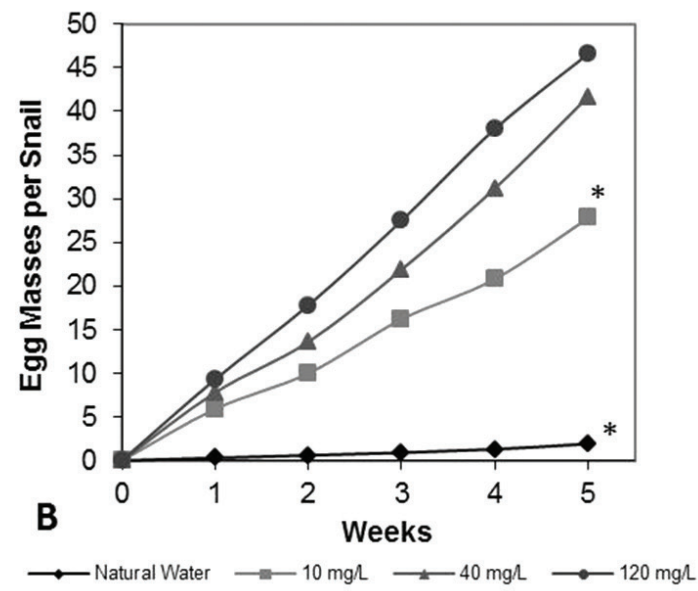

Figure 1. Effects of water hardness on the fecundity of B. glabrata snails. Data are shown as cumulative means of eggs (A) and egg-masses (B) laid per snail. Differences ( $\mathrm{p}<0.05$ ANOVA and Dunnett's multiple comparisons test) from $40 \mathrm{mg} / \mathrm{L}$ $\mathrm{CaCO}_{3}(\mathrm{SW} 2)$ are indicated by an asterisk (*) at the fifth week. 
Assays with positive control (copper sulfate) showed a standardized snails sensitivity as presented in Table 1 . In the five assays carried out, the values obtained for 24 hours LC $_{50}$ were within variability limits (average \pm 2 standard deviation), considered acceptable by the current ecotoxicological protocols.

\section{Discussion}

Several studies show that water hardness is a factor that can significantly interfere in the aquatic ecotoxicity of chemicals, especially metals. In general, water with higher hardness has an effect on reducing toxicity (Sprague, 1995; Yim et al., 2006; Deleebeeck et al., 2007; Ebrahimpour et al., 2010). This effect results from the competition for the biotic ligand between metals and other elements in solution, including calcium (Di Toro et al., 2001). On the other hand, calcium is an essential element in the formation of shells and carapaces of a larger number of invertebrates and has been suggested as a key to the distribution and success of several freshwater species (Robertson, 1941; Young, 1975a; Meyran, 1998). Studies on the possible ways of supplying calcium by molluscs have established that most of it comes directly from the water, around $80 \%$, and part from the diet, around 20\% (Van der Borght and Van Puymbroeck, 1966; Young, 1975b).

In field observations related to water chemistry, Boycott (1936) classified two groups of molluses, the calciphiles, which are those species requiring an environmental calcium level of at least $20 \mathrm{mg} \mathrm{L}^{-1}$ and noncalciphiles, which can resist a wide range of calcium concentrations including those lower than tolerated by calciphiles.

In crustaceans, calcium is mainly located in the skeleton as calcium carbonate. The presence of this element is critical in all molting stages and can be obtained from water and food, but mostly from water (Greenaway, 1985). With gastropods, Kiehn et al. (2004) observed that calcium is not only important for shell formation, but also has a key role in the albumem gland and in the release of perivitelline fluid, which forms the egg-masses.

Data from the present study clearly showed that variation in water hardness considerably changed the reproductive performance of the snail Biomphalaria glabrata, therefore making this a limiting factor for the presence of the species in certain environments. Similar results were obtained by Williams (1970) in a series of laboratory experiments

Table 1. Lethal concentrations $50 \%$ and confidence limits (95\%) of the copper sulfate $(\mathrm{mg} / \mathrm{L})$ to B. glabrata, after 24 hours exposure, over five consecutive weeks.

\begin{tabular}{cc}
\hline Week & 24-h $\mathbf{~ L C}_{50}(\mathbf{m g} / \mathbf{L})$ \\
\hline 1 & $1.84(1.25-2.73)$ \\
2 & $1.25(0.45-3.47)$ \\
3 & $1.58(1.13-2.22)$ \\
4 & $2.31(1.46-3.65)$ \\
5 & $1.50(1.00-2.24)$ \\
Average \pm Standard Deviation & $1.69 \pm 0.40$ \\
\hline
\end{tabular}

using B. pfeifferi, which demonstrated that the maximum rate of population growth occurred in test waters within the range of 20 to $200 \mathrm{mg} / \mathrm{L} \mathrm{CaCO}_{3}$. In soft water (under $20 \mathrm{mg} / \mathrm{L} \mathrm{CaCO}_{3}$ ) the survival and reproduction of snails were poor. With the microcrustacean Ceriodaphnia dubia, Harmon et al. (2003) observed a significant reduction in reproduction when the organisms cultured in moderately hard water were exposed to low hardness waters from streams in South Carolina, USA. The effects of hardness and alkalinity on the reproduction of C. dubia in cultivation water and in tests with water samples were evaluated by Lasier et al. (2006). Results showed that reproduction was significantly reduced when the waters tested had lower hardness than the cultivation water.

In assessing the quality of surface waters in the Brazilian Cerrado, Muniz et al. (2011) observed acute toxicity of natural waters to C.dubia, and absence of toxicity of water from the same river at points further downstream where the water hardness was shown to be higher. According to Lasier et al. (2006), one of the weaknesses in the recommendations of test procedures for aquatic toxicity is associated with stress caused by exposure to a sudden change in water hardness. This situation can be found when hardness levels of the natural waters or effluents are significantly lower than those found in the cultivation water of test organisms.

It should be noted that from the ecotoxicological standpoint all these observations suggest two clear consequences. The first is that in very soft waters aquatic species become more susceptible to the action of toxicants. The second is that in laboratory tests with environmental samples, very soft water can be toxic in itself, thus presenting a paradox to the principles of toxicology, since the toxic effect is not made evident by the presence of chemicals, but by their absence.

Recent studies have shown the concern of scientists with the water quality criteria established by governments and the possible influence of regional water hardness on the ecotoxicity of chemicals (Elphick et al., 2011; Freitas and Rocha, 2011; Gandhi et al., 2011). However, the present research focuses on a different issue, which is the toxicity presented by water hardness and how this parameter can interfere with ecotoxicological assays established as a water quality criterion.

\section{Conclusions}

Ecotoxicological tests require the standardization of parameters, usually making them appropriate to the organisms under cultivation. However, in some cases, the setting of these parameters may affect the results of experiments with environmental samples, because the standards for maintaining colonies in laboratories do not reproduce faithfully the conditions of the samples to which the test organism is exposed during the test. The data from this work show that the snail Biomphalaria glabrata does not have feasible reproduction in water hardness $\leq 10 \mathrm{mg} / \mathrm{L}$ $\mathrm{CaCO}_{3}$ and, in these cases, ecotoxicological studies using 
natural waters with parameters like this can be harmed by the natural chemistry of the water itself.

In conclusion, since the water quality criteria in Brazil and elsewhere are based, among other parameters, on ecotoxicological testing, this study indicates that test organisms should be maintained in conditions similar to those specific to their region, particularly with respect to the water hardness. Otherwise, assays may be uncertain and clean natural waters may be wrongly evaluated as toxic.

Acknowledgements - This work was supported by the National Council for Scientific and Technological Development CNPq, Project 472223/2007-0. Nathalia Ribeiro Caixeta and Nathan Soares de Castro Simplício received grants from PIBIC/UniCEUB and from PIC/CNPq, respectively.

\section{References}

Associação Brasileira de Normas Técnicas - ABNT, 1992. NBR 12621: Água - Determinação da dureza total - Método titulométrico do EDTA-No método de ensaio. Rio de Janeiro: ABNT.

-, 2004. NBR 15088: Ecotoxicologia aquática - Toxicidade aguda - Método de ensaio com peixes. Rio de Janeiro: ABNT.

-, 2005. NBR 13373: Ecotoxicologia aquática - Toxicidade Crônica - Método de ensaio com Ceriodaphnia spp (Cladocera, Crustácea). Rio de Janeiro: ABNT.

ARAGÃO, MA., BURATINI, SV. and BERTOLETTI, E., 2003. total hardness of surface waters in São Paulo state (Brazil). Acta Limnologica Brasiliensia, vol. 15, no. 1, p. 15-18.

BELLAVERE, C. and GORBI, J., 1981. Comparative analysis of acute toxicity of chromium, copper and cadmium to Daphnia magna, Biomphalaria glabrata and Brachydanio rerio. Environmental Technology Letters, vol. 2, no. 3, p. 119-128. http://dx.doi. org/10.1080/09593338109384031

BOYCOTT, AE., 1936. The habitats of the freshwater Mollusca in Britain. Journal of Animal Ecology, vol. 5, no. 1, p. 116-186. http://dx.doi.org/10.2307/1096

BRASIL. Ministério do Meio Ambiente. Conselho Nacional do Meio Ambiente, 2005. Resolução n 357, de 17 de março de 2005. Diário Oficial da República Federativa do Brasil, Brasília, 18 mar. Seção 1, p. 58-63.

BRITO, LTL., SRINIVASAN, VS., SILVA, AS., GHEYI, HR., GALVÃO, CO. and HERMES, LC., 2005. Influência das atividades antrópicas na qualidade das águas da bacia hidrográfica do Rio Salitre. Revista Brasileira de Engenharia Agricola e Ambiental, vol. 9, no. 4, p. 596-602. http://dx.doi.org/10.1590/S141543662005000400025

DELEEBEECK, NME., MUYSSEN, BTA., DE LAENDER, F., JANSSEN, CR. and DE SCHAMPHELAERE, KAC., 2007. Comparison of nickel toxicity to cladocerans in soft versus hard surface waters. Aquatic Toxicology, vol. 84, no. 2, p. 223-235. PMid:17659789. http://dx.doi.org/10.1016/j.aquatox.2007.03.025

DI TORO, DM., ALLEN, HE., BERGMAN, HL., MEYER, JS., PAQUIN, PR. and SANTORE, RC., 2001. Biotic ligand model of the acute toxicity of metals. I. Technical basis. Environmental Toxicology and Chemistry, vol. 20, no. 10, p. 2378-2396. http:// dx.doi.org/10.1002/etc.5620201034
DUNNETT, CW., 1955. Multiple comparison procedure for comparing several treatments with a control. Journal of the American Statistical Association, vol. 50, n. 272, p. 1096-1121. http://dx.doi.org/10.1080/01621459.1955.10501294

EBRAHIMPOUR, M., ALIPOUR, H. and RAKHSHAH, S., 2010. Influence of water hardness on acute toxicity of copper and zinc on fish. Toxicology and Industrial Health, vol. 26, no. 6, p. 361-365. PMid:20504831. http://dx.doi.org/10.1177/0748233710369123

ELPHICK, JR., BERGH, KD. and BAILEY, HC., 2011. Chronic toxicity of chloride to freshwater species: effects of hardness and implications for water quality guidelines. Environmental Toxicology and Chemistry, vol. 30, no. 1, p. 239-246. PMid:20872898. http:// dx.doi.org/10.1002/etc.365

FREITAS, EC. and ROCHA, O., 2011. Acute and chronic toxicity of chromium and cadmium to the tropical cladoceran pseudosida ramosa and the implications for ecotoxicological studies. Environmental Toxicology, vol. 29, no. 2, p. 176-186. PMid:22038926. http://dx.doi.org/10.1002/tox.20784

GANDHI, N., HUIJBREGTS, M.A., MEENT, D., PEIJNENBURG, WJ., GUINÉE, J. and DIAMOND, ML., 2011. Implications of geographic variability on comparative toxicity potentials of $\mathrm{Cu}, \mathrm{Ni}$ and $\mathrm{Zn}$ in freshwaters of Canadian ecoregions. Chemosphere, vol. 82, no. 2, p. 268-277. PMid:20934738. http://dx.doi.org/10.1016/j. chemosphere.2010.09.046

GREENAWAY, P., 1985. Calcium balance and moulting in the crustacea. Biological Reviews, vol. 60, no. 3, p. 425-454. http:// dx.doi.org/10.1111/j.1469-185X.1985.tb00424.x

HAMILTON, MA., RUSSO, RC. and THURSTON, RV., 1977. Trimmed Spearman-Karber method for estimating median lethal concentrations in toxicity bioassays. Environmental Science and Technology, vol. 11, no. 7, p. 714-719. http://dx.doi.org/10.1021/ es60130a004

HARMON, SM., SPECHT, WL. and CHANDLER, GT., 2003. A comparison of the daphnids Ceriodaphnia dubia and Daphnia ambigua for their utilization in routine toxicity testing in the southeastern United States. Archives of Environmental Contamination and. Toxicology, vol. 45, no. 1, p. 79-85. PMid:12948176. http:// dx.doi.org/10.1007/s00244-002-0116-8

HORBE, AMC., GOMES, ILF., MIRANDA, SF. and SILVA, MSR., 2005. Contribuição à hidroquímica de drenagens no município de Manaus - AM. Acta Amazonica, vol. 35, no. 2, p. 119-124. http://dx.doi.org/10.1590/S0044-59672005000200002

KIEHN, L., MUKAI, ST. and SALEUDDIN, ASM., 2004. The role of calcium on protein secretion of the albumem gland in Helisomaduryi (Gastropoda). Invertebrate Biology, vol. 123, no. 4, p. 304-315. http://dx.doi.org/10.1111/j.1744-7410.2004.tb00164.x

LASIER, PJ., WINGER, PV. and HARDIN, IR., 2006. Effects of hardness and alkalinity in culture and test waters on reproduction of Ceriodaphnia dubia. Environmental Toxicology and Chemistry, vol. 25 , no. 10 , p. 2781-2786. PMid:17022421. http://dx.doi. org/10.1897/05-547R.1

MEYRAN, JC., 1998. Ecophysiological diversity of alpine populations of Gammarus lacustris in relation to environmental calcium. Freshwater Biology, vol. 39, no. 1, p. 41-47. http:// dx.doi.org/10.1046/j.1365-2427.1998.00257.x

MUNIZ, DHF., MORAES, AS., CRUZ, CJD., LIMA, JEFW. and OLIVEIRA-FILHO, EC., 2011. Evaluation of water quality parameters for monitoring natural, urban, and agricultural areas in 
the Brazilian savanna. Acta Limnologica Brasiliensia, vol. 23, no. 3, p. 307-317. http://dx.doi.org/10.1590/S2179-975X2012005000009

MÜNZINGER, A., 1987. Biomphalaria glabrata (Say), a suitable organism for a biotest. Environmental Technology Letters, vol. 8 , no. 1 , p. 307-317.

OLIVEIRA-FILHO, EC., LOPES, RM. and PAUMGARTTEN, FJ., 2004. Comparative study on the susceptibility of freshwater species to copper-based pesticides. Chemosphere, vol. 56, no. 4, p. 369-374. PMid:15183999. http://dx.doi.org/10.1016/j. chemosphere.2004.04.026

OLIVEIRA-FILHO, EC., GERALDINO, BR., GRISOLIA, CK. and PAUMGARTTEN, FJ., 2005. Acute toxicity of endosulfan, nonylphenol ethoxylate, and ethanol to different life stages of the freshwater snail Biomphalaria tenagophila (Orbigny, 1835). Bulletin of Environmental Contamination and Toxicology, vol. 75, no. 6, p. 1185-1190. PMid:16402310. http://dx.doi.org/10.1007/ s00128-005-0874-x

OLIVEIRA-FILHO, EC., DA-MATTA, AC., CABRAL, LL., VEIGA, LF. and PAUMGARTTEN, FJ., 2008. Comparison between four and seven-day Ceriodaphnia dubia survival and reproduction test protocols using oil refinery effluent samples. Brazilian Archives of Biology and Technology, vol. 51, no. 1, p. 137-142. http://dx.doi.org/10.1590/S1516-89132008000100017

OLIVEIRA-FILHO, EC., GRISOLIA, CK. and PAUMGARTTEN, FJ., 2009a. Trans-generation study of the effects of nonylphenol ethoxylate on the reproduction of the snail Biomphalaria tenagophila. Ecotoxicology and Environmental Safety, vol. 72, no. 2, p. 458-465. PMid:18061673. http://dx.doi.org/10.1016/j. ecoenv.2007.10.008

-, 2009b. Effects of endosulfan and etanol on the reproduction of the snail Biomphalaria tenagophila: a multigeneration study. Chemosphere, vol. 75, no. 3, p. 398-404. PMid:19138786. http:// dx.doi.org/10.1016/j.chemosphere.2008.11.085

OLIVEIRA-FILHO, EC., GERALDINO, BR., COELHO, DR., DECARVALHO, RR. and PAUMGARTTEN, FJ., 2010. Comparative toxicity of Euphorbia milii latex and synthetic molluscicides to Biomphalaria glabrata embryos. Chemosphere, vol. 81, no. 2, p. 218-227. PMid:20594574. http://dx.doi.org/10.1016/j. chemosphere.2010.06.038

OLIVIER, L. and HASKINS, W.T., 1960. The effects of low concentrations of sodium pentachlorophenate on the fecundity and egg viability of Australorbis Glabratus. American Journal of Tropical Medicine and Hygiene, vol. 9, p. 199-205. PMid:14428737.

RAVERA, O., 1977. Effects of heavy metals (cadmium, copper, chromium and lead) on a freshwater snail: Biomphalaria glabrata
Say (Gastropoda, Prosobranchia). Malacologia, vol. 16, no. 1, p. 231-236. PMid:904367.

ROBERTSON, JD., 1941. The function and metabolism of calcium in the invertebrata. Biological Reviews, vol. 16, no. 2, p. 106-133. http:dx.doi.org/ 10.1111/j.1469-185X.1941.tb01097.x http://dx.doi.org/10.1111/j.1469-185X.1941.tb01097.x

SAVOY, VLT., PRISCO, RCB. and ALMEIDA, SDB., 2004. Determinação da dureza da água em regiões agrícolas do estado de São Paulo. Arquivos do Instituto Biologico, vol. 71, no. 3, p. 387-389

SPRAGUE, JB., 1995. Factors that modify toxicity. In: Rand, GM. Fundamentals of aquatic toxicology: effects, environmental fate and risk assessment. Washington: Taylor \& Francis, p. 1012-1051.

United States Environmental Protection Agency - USEPA, 1976. Quality criteria for water. USEPA: Washington. EPA-440/9-76023, $501 \mathrm{p}$.

-, 2002. Short-term methods for estimating the chronic toxicity of effluents and receiving waters to freshwater organisms. Washington: USEPA. EPA-821-R-02-013. 335 p.

VAN DER BORGHT, O. and VAN PUYMBROECK, S., 1966. Calcium metabolism in a freshwater mollusk: quantitative importance of water and food as supply for calcium during growth. Nature, vol. 210, no. 5038, p. 791-793. PMid:5958443. http://dx.doi.org/10.1038/210791a0

WILLIAMS, NV., 1970. Studies on aquatic pulmonate snails in central africa. II. experimental investigation of field distribution patterns. Malacologia, vol. 10, p. 165-180.

WURTS, WA., 1993. Understanding water hardness. World aquaculture, vol. 24, no. 1, p. 18.

YIM, JH., KIM, KW. and KIM, SD., 2006. Effect of hardness on acute toxicity of metal mixtures using Daphnia magna: prediction of acid mine drainage. Journal of Hazardous Materials, vol. 138, no. 1, p. 16-21. PMid:16806685. http://dx.doi.org/10.1016/j. jhazmat.2005.11.107

YOUNG, JO., 1975a. Preliminary field and laboratory studies on the survival and spawning of several species of gastropoda in calcium-poor and calcium-rich waters. Proceedings of the Malacological Society of London, vol. 41, no. 5, p. 429-437.

-, 1975b. A laboratory study, using $45 \mathrm{Ca}$ tracer, on the source of calcium during growth in two freshwater species of gastropoda. Proceedings of the Malacological Society of London, vol. 41, no. 5, p. 439-445. 